\title{
冰期气候突变的高低纬同步性
}

\author{
张旭 ${ }^{1,2^{*}}$, 刘小康 ${ }^{3}$, 张炜晨 $^{1}$
}

1. 兰州大学资源环境学院, 泛三极生态环境与气候变化前沿中心, 西部环境教育部重点实验室, 兰州 730000;

2. 中国科学院青藏高原地球科学卓越创新中心, 北京 100101 ;

3. 中国科学院青藏高原研究所, 中国科学院高寒生态重点实验室, 北京 100101

* 联系人, E-mail: zhangxu@1zu.edu.cn

\section{Synchronicity of abrupt climate changes during the last glacial period}

\author{
Xu Zhang ${ }^{1,2^{*}}$, Xiaokang Liu ${ }^{3} \&$ Weichen Zhang ${ }^{1}$ \\ ${ }^{1}$ Key Laboratory of Western China's Environmental Systems (Ministry of Education), Center for Pan Third Pole Environment (Pan-TPE), College of Earth \\ and Environmental Science, Lanzhou University, Lanzhou 730000, China; \\ ${ }^{2}$ Center for Excellence in Tibetan Plateau Earth Sciences, Chinese Academy of Sciences, Beijing 100101, China; \\ ${ }^{3}$ Key Laboratory of Alpine Ecology, Institute of Tibetan Plateau Research, Chinese Academy of Sciences, Beijing 100101, China \\ * Corresponding author, E-mail: zhangxu@ @ lzu.edu.cn \\ doi: 10.1360/TB-2020-1201
}

一项最新发表在 Science 上的研究表明 ${ }^{[1]}$, 北极格陵 兰岛冰芯记录的末次冰期中发生的气候突变事件与中低 纬度的气候变化是同时发生的.

由于积雪年复一年的堆积, 地球两极的格陵兰岛和南 极大陆形成了厚厚的冰盖. 冰盖中不同冰层间的微小气泡, 保留了当时大气的水分子和其他粒子, 为我们了解地质历 史时期的地球古气候和古环境提供了独一无二的记录载 体. 例如, 气泡中的化学成分可以记录过去的温室气体(比 如二氧化碳)的水平, 而火山灰或沙尘则暗示着强大的火 山喷发或显著的全球干旱. 它们像古生物化石, 勾勒出过 去特定时段的古气候特征. 因此, 从冰川或者冰盖中钻取 的长冰芯记录, 为我们了解地球历史上发生过的复杂气候 变化提供了一把钥匙. 其中, 冰芯中氧同位素比值 $\left(\delta^{18} \mathrm{O}\right.$, 指质量数为 18 的氧原子所占比率与标准平均海洋水的偏 差再乘以 1000)的变化, 与当地气温有着密不可分的联 ${ }^{\text {系 }}{ }^{[2]}$, 为我们重建过去大气温度的变化提供了可能.

格陵兰岛的冰芯钻孔记录了地球历史中的最后一次冰 期旋回 (即末次冰期, 时间范围为过去约 115 11.7 ka). 最早 是由 Dansgaard 和 Oeschger 于 1982 年发现了冰芯 $\delta^{18} \mathrm{O}$ 记录 中一系列反复、剧烈的快速冷暖交替的信号, 在 1993 年再 次确认后, 这一现象被命名为 Dansgaard-Oeschger (DO)事 件 ${ }^{[3]}$. 在 DO 事件期间, 格陵兰岛的年均气温可在短短数十 年内 (人类寿命范围内) 迅速升高 $8 \sim 16^{\circ} \mathrm{C}$, 当地气候进人一 个相对暖的时期, 即间冰阶期; 之后温度逐渐下降, 最后 迅速进人一个相对冷的时期, 即冰阶期. 这一过程反映了
气候系统的非线性变化特征, 而 Broecker 和 Denton ${ }^{[4]}$ 提出 的大洋传送带动力机制过程来解释这一特征是目前较为 主流的观点.

大洋传送带是一个理论上的贯穿全球各大洋的物质 能量输运带, 其在大西洋的部分又名大西洋经向翻转流 (Atlantic meridional overturning circulation, AMOC), 可将 赤道附近的低纬度大西洋甚至南半球的热量向北输送至 大西洋北部及北欧海, 这些暖水在此失热后变重下沉, 形 成北大西洋底层水, 再经大西洋底部流回南大洋. 因此, AMOC 的减弱或停滞将导致北半球高纬度地区的变冷和 南半球的变暖, 由此引起南北半球经向(沿经线方向)温度 梯度的变化, 使得热带辐合带 (intertropical convergence zone, ITCZ)(雨带)位置南移, 并导致北半球夏季降水减 少、南半球降水增多. 如果实际情况与理论推测一样, 那 么格陵兰的温度变化与 ITCZ 相关的降水应该有几乎同步 的响应. 但这一推测目前仍缺少可靠的证据, 主要难点在 于如何确定格陵兰 DO 事件与中低纬度地区的气候变化是 否同步.

为了验证二者的同步性, 需要分别从高纬和低纬地区 获得足够多且精确定年的古气候记录, 分析它们在 DO 事 件发生时的先后顺序. 虽然现在有大量公开发表的冰芯、 海洋沉积物等古气候记录, 但它们因为定年误差偏大, 并 不适用于该方面的研究.

在岩溶(或喀斯特)地区广泛发育的洞穴沉积物是研 究以上科学问题的良好载体. 洞穴内部的次生碳酸盐, 包 
括钟乳石和石笋等, 是由洞穴顶部裂隙中渗透而下的滴 水(含有碳酸氢根离子和氢离子) 在洞穴内部的滴水点缓慢 沉积碳酸钙而形成. 石笋沉积过程中会随着时间形成旋
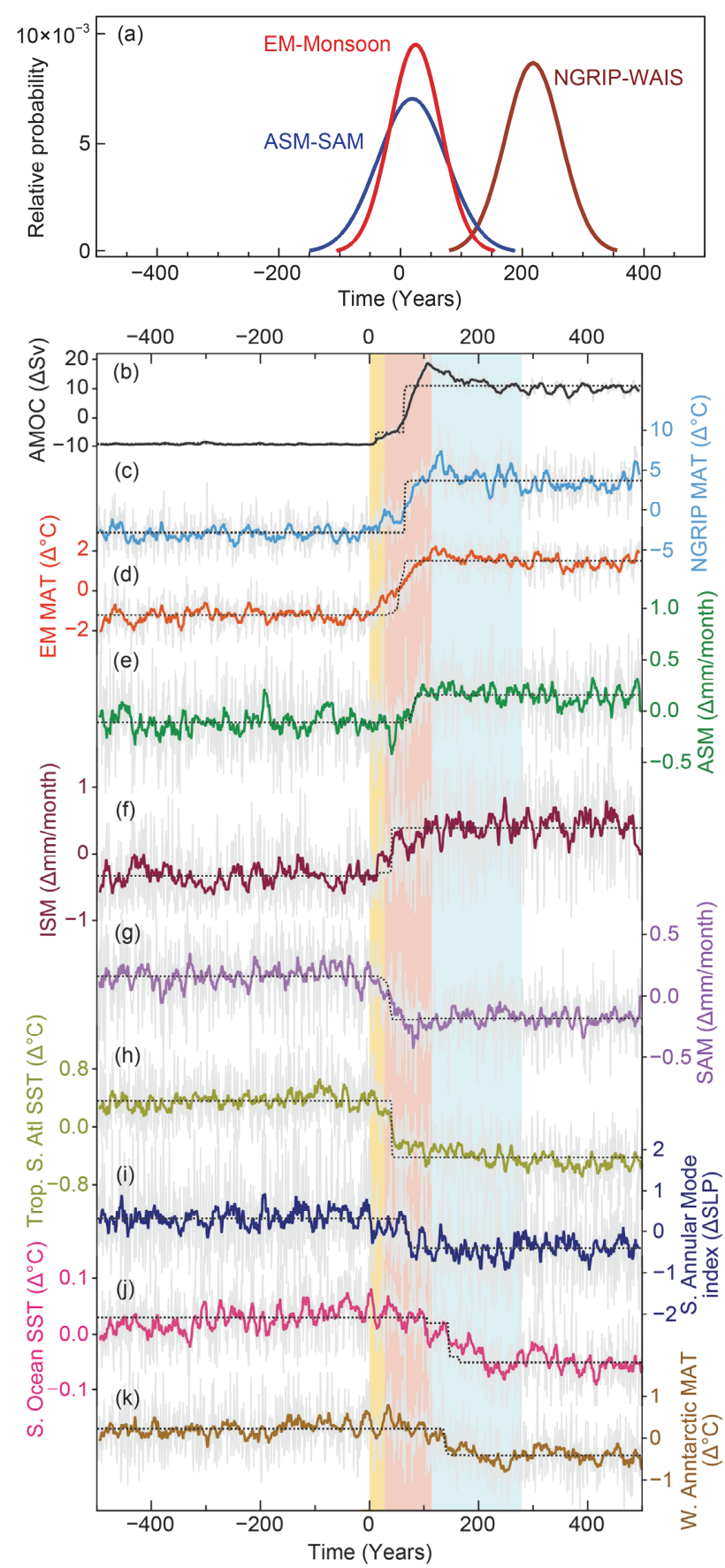

图 1 DO 事件发生时全球不同地区的气候响应 ${ }^{[1]}$. (a) 根据洞穴 石笋 $\delta^{18} \mathrm{O}$ 记录集成所得的两个季风区(亚洲夏季风(ASM)与南美 季风区 (SAM), 蓝色), 以及欧洲和两个季风区(欧洲-地中海(EM) 与季风区，红色)之间的空间年龄偏移量的概率分布函数(PDFs), 以及先前发表的南极 WAIS 冰芯 $\delta^{18} \mathrm{O}$ 记录与北极 NGRIP 冰芯
回层(层理), 其氧同位素 $\left(\delta^{18} \mathrm{O}\right)$ 信号可用来大致反映碳酸 钙生成时的洞穴内部温度和大气降水同位素变化. 更重要 的是，这些沉积物(岩)可使用一种称为铀钍定年的放射性

$\delta^{18} \mathrm{O}$ 记录之间的偏移量 (棕色 $)^{[13]}$. (b) (k) DO 期间模型注水实验的 气候变化, 每条曲线均表示相对于模拟数据平均值的差异变化. (b) 北大西洋经向翻转流(AMOC)指数(定义为北大西洋 $45^{\circ} \mathrm{N}$ 以 北 300 1500 m 水域经向流函数的最大值); (c) NGRIP 冰芯钻孔所 在位置的表层年均气温(NGRIP MAT); (d) 欧洲-地中海地区的表 层年均气温 $\left(30^{\circ} \sim 45^{\circ} \mathrm{N}, 25^{\circ} \sim 40^{\circ} \mathrm{E}\right)(\mathrm{EM} \mathrm{MAT})$; (e) 东亚地区 $\left(20^{\circ} \sim\right.$ $\left.30^{\circ} \mathrm{N}, 108^{\circ} \sim 120^{\circ} \mathrm{E}\right)$ 年均降水量; (f) 印度地区 $\left(25^{\circ} \sim 35^{\circ} \mathrm{N}, 75^{\circ} \sim 85^{\circ} \mathrm{E}\right)$ 年均降水量; (g) 南美地区 $\left(5^{\circ} \sim 10^{\circ} \mathrm{S}, 30^{\circ} \sim 75^{\circ} \mathrm{W}\right)$ 年均降水量; (h) 热带-亚热带大西洋 $\left(5^{\circ} \sim 30^{\circ} \mathrm{S}, 60^{\circ} \mathrm{W} \sim 10^{\circ} \mathrm{E}\right)$ 年均海平面温度; (i) 反 映海平面气压从 $20^{\circ} \sim 90^{\circ} \mathrm{S}$ 变化的南半球环状模态指数; (j) 南大 洋 $\left(55^{\circ} \sim 75^{\circ} \mathrm{S}, 60^{\circ} \mathrm{W} 10^{\circ} \mathrm{E}\right)$ 年均海平面温度; (k) 南极大陆西部 $\left(75^{\circ} \sim 82^{\circ} \mathrm{S}, 90^{\circ} \sim 135^{\circ} \mathrm{W}\right)$ 表层气温, 可代表 WAIS 冰芯位置上空的 表层气温. 黄色阴影表示大气对大西洋 ITCZ 开始向亚热带北大 西洋迁移的快速响应期, 粉红色阴影表示 $\mathrm{AMOC}$ 和北半球变暖进 一步加强的时期, 蓝色阴影表示 AMOC 开始转变为间冰阶模式. 灰色曲线是原始模型输出序列, 其他彩色曲线为 11 年滑动平均 后的序列. 黑色虚线为应用贝叶斯和最小二乘法对每条原始时间 序列进行分析后导出的模式序列. (a)中年份是指每个概率分布函 数的偏移年数; (b) (k)中横坐标为模式年份, 第 1 年重置为除去淡 水通量的年份. 因此, (a)中 NGRIP-WAIS 概率分布函数曲线相对 于(b) (k)中的模式年份比例处于近似正确的位置

Figure 1 Spatial synchrony of climate changes during interstadial onsets $^{[1]}$. (a) Probability distribution function (PDFs) of spatial age offsets between the two monsoon regions (ASM minus SAM, blue) and between Europe and both monsoon regions (EM minus Monsoon, red) based on composite speleothem data. Also shown (brown) is the previously determined offset between the WAIS ice core $\delta^{18} \mathrm{O}$ and NGRIP $\delta^{18} \mathrm{O}^{[13]}$. (b)-(k) Simulated climate changes in a DO-type hosing simulation, each expressed as anomalies from the mean of the simulation. (b) AMOC index (defined as maximal meridional stream function at the water depth of 1500 to $3000 \mathrm{~m}$ north of $45^{\circ} \mathrm{N}$ in the North Atlantic). (c) Annual mean surface air temperature over the NGRIP drilling site (NGRIP MAT). (d) Annual mean surface air temperature over the Europe-Mediterranean region $\left(30^{\circ}-45^{\circ} \mathrm{N}, 25^{\circ}-40^{\circ} \mathrm{E}\right)$ (EM MAT). (e) $-(\mathrm{g})$ Mean annual precipitation over the Eastern Asian $\left(20^{\circ}-30^{\circ} \mathrm{N}, 108^{\circ}-120^{\circ} \mathrm{E}\right)(\mathrm{e})$, Indian $\left(25^{\circ}-35^{\circ} \mathrm{N}, 75^{\circ}-85^{\circ} \mathrm{E}\right)(\mathrm{f})$, and South American regions $\left(5^{\circ}-10^{\circ} \mathrm{S}, 30^{\circ}-75^{\circ} \mathrm{W}\right)(\mathrm{g})$. (H) Annual mean sea-surface temperature (SST) in the tropical-subtropical South At lantic $\left(5^{\circ}-30^{\circ} \mathrm{S}, 60^{\circ} \mathrm{W}-10^{\circ} \mathrm{E}\right)$. (i) Southern Annular Mode index reflecting changes in sea-level pressure from $20^{\circ}-90^{\circ} \mathrm{S}$. (j) Annual mean SST in the Atlantic sector of the Southern Ocean $\left(55^{\circ}-75^{\circ} \mathrm{S}\right.$, $\left.60^{\circ} \mathrm{W}-10^{\circ} \mathrm{E}\right)$. (k) MAT over West Antarctica $\left(75^{\circ}-82^{\circ} \mathrm{S}, 90^{\circ}-135^{\circ} \mathrm{W}\right)$ taken to be representative of the WAIS ice core site. Yellow shading indicates the period of fast atmospheric response in which the Atlantic ITCZ starts migrating toward the subtropical North Atlantic. Pink shading indicates the period of further strengthening of the AMOC and $\mathrm{NH}$ warming. Blue shading indicates the start of the AMOC interstadial mode. The gray series are raw model outputs, and the color series are 11-year running averages. The black dotted lines are model series derived from the application of a Bayesian, least-squares change-point analysis to each raw time series. For (b)-(k), the $x$ axis shows model years, with year 1 reset to the year of the removal of the freshwater flux. For (a), the year scale refers to the age offset for each PDF. The NGRIP-WAIS PDF curve is therefore in its approximate correct position with respect to the model-year scale in $(\mathrm{b})-(\mathrm{k})$ 
同位素测试技术, 精确地测定不同的沉积旋回形成时的绝 对年龄 ${ }^{[5]}$, 且年龄误差远远小于同时期的冰芯和海洋沉积 物记录. 这为解答高、低纬气候变化的时间同步性提供了 可能.

2020 年 8 月 21 日, Science 在线发表了来自澳大利 亚、法国、中国、丹麦、瑞士、英国的国际科研团队合作 完成的最新研究成果 ${ }^{[1]}$. 该研究工作通过收集来自中低纬 度地区的 63 个有较高时间分辨率和精确年龄框架的石笋 $\delta^{18} \mathrm{O}$ 古气候记录, 结合南北极的冰芯数据, 首次证实了高 低纬气候系统在 DO 爆发时几乎是同步变化的, 并进而发 现石笋古气候记录的气候突变与模拟试验中区域气候对 AMOC 重启的响应具有很好的一致性(图 1). 这确认了 $\mathrm{AMOC}$ 变化是引起高低纬气候同步响应的主因, 再次证实
了 AMOC 变化与过去气候突变事件之间密不可分的联系. 对于 DO 事件爆发后的全球气候响应, 我们已经有了 比较充分的认识, 但相关的动力学过程仍有不确定之处. 目前, 解释 AMOC 变化的主流观点可分为两类: 第一类强 调 $\mathrm{AMOC}$ 的双稳态的特征 ${ }^{[6-9]}$, 即在同一气候背景下 AMOC 存在两种截然不同的气候态, 此时 AMOC 对外力 变化非常敏感, 随机性的气候噪音就可能导致气候突变的 发生; 第二类强调 AMOC 本身具有自震荡的特征 ${ }^{[10 ~ 12]}$, 即 在某一气候背景下, AMOC 是不稳定的、震荡的, 因此即 使无外力的介人, 气候突变依然可以发生. 这两类观点在 理论上给出了大西洋径向翻转流突变的动力框架, 但遗憾 的是, 触发其变化的因素依然不清晰, 这将是该领域未来 研究的重点方向之一.

\section{推葆阅读文献}

1 Corrick E C, Drysdale R N, Hellstromet J C, et al. Synchronous timing of abrupt climate changes during the last glacial period. Science, 2020, 369: 963-969

2 Jouzel J. Water stable isotopes: Atmospheric composition and applications in polar ice core studies. In: Holland H D, Turekian K K, eds. Treatise on Geochemistry. 2nd Ed. 2014, 5: 213-256

3 Dansgaard W S, Johnsen J, Clausen H B, et al. Evidence for general instability of past climate from a 250-kyr ice-core record. Nature, 1993, 364: 218-220

4 Broecker W, Denton G. The role of ocean-atmosphere reorganization in glacial cycles. Geochim Cosmochim Acta, 1989, 53: 2465-2501

5 Cheng H, Edwards R L, Shen C C, et al. Improvements in ${ }^{230}$ Th dating, ${ }^{230} \mathrm{Th}$ and ${ }^{234} \mathrm{U}$ half-life values, and U-Th isotopic measurements by multi-collector inductively coupled plasma mass spectrometry. Earth Planet Sci Lett, 2013, 371-372: 82-91

6 Stommel H. Thermohaline convection with two stable regimes of flow. Tellus, 1961, 13: 224-230

7 Ganopolski A, Rahmstorf S. Rapid changes of glacial climate simulated in a coupled climate model. Nature, 2001, 409: 153-158

8 Zhang X, Lohmann G, Knorr G, et al. Abrupt glacial climate shifts controlled by ice sheet changes. Nature, 2014, 512: 290-294

9 Zhang X, Knorr G, Lohmann G, et al. Abrupt North Atlantic circulation changes in response to gradual $\mathrm{CO}_{2}$ forcing in a glacial climate state. Nat Geosci, 2017, 10: 518-523

10 Winton M. Deep decoupling oscillations of the oceanic thermohaline circulation. In: Peltier W R, ed. Ice in the Climate System. Berlin: Springer, 1993. 417-432

11 Peltier W R, Vettoretti G. Dansgaard-Oeschger oscillations predicted in a comprehensive model of glacial climate: A 'kicked' salt oscillator in the Atlantic. Geophys Res Lett, 2014, 41: 7306-7313

12 Brown N, Galbraith E D. Hosed vs. unhosed: Interruptions of the Atlantic Meridional Overturning Circulation in a global coupled model, with and without freshwater forcing. Clim Past, 2016, 12: 1663-1679

13 WAIS Divide Project Members. Precise interpolar phasing of abrupt climate change during the last ice age. Nature, 2015, 520: 661-665 